\title{
OPTIMALISASI PENEGAKAN HUKUM PIDANA DI BIDANG LINGKUNGAN HIDUP MELALUI PRINSIP PRIMUM REMEDIUM
}

\author{
Lona Puspita, SH.MH \\ Dosen Fakultas Hukum Tamansiswa Padang
}

\begin{abstract}
Laws relating to environmental management contain explicit provision on the application of the principle ultimium Remedium Remedium and Premium. This provision has been included since the law undag environmental management in 1997, which then undergoes changes in environmental legislation in 2009. There are differences in regulation and the application of the principle Utimum or Premium Remedium in Act No. 23 of 1997 by Law No. 32 of 2009. Act No. 23 of 1997 emphasizes the application of the principle of ultimum Remedium while Law No. 32 of 2009 put more emphasis on the application of the principle of Primum Remedium in criminal law enforcement environment.
\end{abstract}

\section{A. Pendahuluan}

Undang-undang terkait pengelolaan lingkungan hidup memuat ketentuan yang tegas tentang penerapan asas Ultimum Remedium dan Premium Remedium. Ketentuan ini sudah termuat sejak adanya undangundag pengelolaan lingkungan pada tahun 1997, yang kemudian mengalami perubahan pada undang-undang lingkungan tahun 2009. Terdapat perbedaan pengaturan dan penerapan asas Utimum ataupun Premium Remedium dalam Undang-Undang Nomor 23 Tahun 1997 dengan Undang-Undang Nomor 32 tahun 2009. Undang-Undang Nomor 23 Tahun 1997 lebih menekankan penerapan asas Ultimum Remedium sedangkan UndangUndang Nomor 32 Tahun 2009 lebih menekankan pada penerapan asas Primum Remedium dalam penegakan hukum pidana lingkungan.

\begin{tabular}{lcr}
\multicolumn{3}{c}{ Dalam UU No. 23 Tahun 1997} \\
berlakunya & ketentuan & hukum \\
pidana & memperhatikam & asas \\
Ultimum & Remedium & artinya \\
penegakan & hukum & pidana \\
merupakan & upaya & terakhir \\
bilamana & penegakan & hukum \\
administrasi & perdata & ataupun \\
alternative & penyelesaian & sengketa \\
lingkungan & hidup tidak & efektif. \\
Penegakan & hukum pidana dapat \\
bersifat & Primum & Remedium, \\
bilamana salah satu diantara ketiga \\
hal berikut terjadi :
\end{tabular}

1. Apabila tingkat kesalahan pelaku reletif berat

2. Apabila akibat perbuatan dari pelaku relative besar

\footnotetext{
${ }^{1}$ Masrudi Muchtar, Sistem Peradilan Pidana di Bidang Perlindungan dan Pengelolaan Lingkungan Hidup, 2015, Prestasi Pustaka Jakarta, hlm 170
} 
3. Apabila perbuatan pelaku menimbulkan keresahan masyarakat.

Berbeda dengan UU No. 32 Tahun 2009 lebih menekankan pada asas Primum Remedium walaupun tetap memperhatikan asas Ultimum Remedium. Penerapan asas ultimum remedium hanya berlaku bagi tindak pidana tertentu, yaitu pemidanaan terhadap pelanggaran baku mutu air limbah, emisi dan gangguan. Penerapan asas ultimum remedium dapat dilihat dalam pasal $100 \mathrm{UU}$ No. 32 Tahun 2009 dimana pemidanaan terhadap pelanggaran baku mutu air limbah, emisi dan gangguan hanya dapat dikenakan apabila sanksi administrative yang telah dijatuhkan tidak dipenuhi ataupun pelanggaran tersebut telah dilakukan lebih dari satu kali. ${ }^{2}$

Selain pelanggaran baku mutu air limbah, emisi dan gangguan, bagi semua tindak pidana lingkungan hidup lainnya dapat langsung dikenakan penegakan hukum pidana. Tindak pidana lingkungan hidup yang dapat langsung dikenakan penagakan hukum pidana adalah sebagai berikut :

1. Perbuatan (baik sengaja ataupun tidak) yang mengakibatkan dilampuainya baku mutu udara ambient, baku mutu air, baku mutu air laut atau criteria baku mutu lingkungan hidup (Pasal 98 dan 99 UU No 32 Tahun 2009)

2. Melepaskan dan/atau mengedarkan produk rekayasa genetika ke media lingkungan hidup yang tidak dapat sesuai dengan ketentuan peraturan perundang-undangan (Pasal 101 UU No. 32 Tahun 2009)

3. Mengelola limbah B3 tanpa izin (Pasal 102 UU No. 32 Tahun 2009)

4. Tidak mengelola limbah B3 yang dihasilkan (Pasal 103 UU No. 32 Tahun 2009)

5. Melakukan dumping limbah (Pasal 104 UU No. 32 Tahun 2009)

6. Memasukan limbah (Pasal $105 \mathrm{UU}$ No. 32 Tahun 2009)

7. Memasukan llimbah B3 (Pasal 106 UU No. 32 Tahun 2009)

8. Memasukan B3 yang dilarang (Pasal 107 UU No. 32 Tahun 2009)

9. Membakar lahan (Pasal 108 UU No. 32 Tahun 2009)

10. Melakukan usaha dan/atau kegiatan tanpa memiliki izin lingkungan (Pasal 109 UU No. 32 Tahun 2009)

11. Menyusun AMDAL tanpa memiliki sertifikat kompetensi penyusunan AMDAL (Pasal 110 UU No. 32 Tahun 2009)

12. Menerbitkan izin ingkungan tanpa dilengkapi dengan AMDAL atau ULK-UPL (Pasal 111 UU No. 32 tahun 2009)

13. Menerbitkan izin usaha dan/atau kegiatan tanpa dilengkapi dengan izin lingkungan (pasal 111 ayat 2 UU No. 32 Tahun 2009)

14. Tidak melakukan ketaatan penanggung jawab usaha dan/atau kegiatan terhadap ketentuan peraturan perundang-undangan dan izin lingkungan (pasal 112 UU No. 32 Tahun 2009)

15. Memberika informasi palsu (Pasal 113 UU No. 32 Tahun 2009) 
16. Tidak melaksanakan perintah paksaan pemerintah (Pasal 114 UU No. 32 Tahun 2009)

17. Mencengah, menghalang-halangi ataupun menggagalkan pelaksanaan tugas pejabat pengawas llingkungan hidup dan/atau penyidik PPNS (pasal 115 UU No. 32 Tahun 2009)

\section{B. Pembahasan}

\section{B.1 Prinsip Ultimum Remedium dan Prinsip Primum Remedium dalam Undang Undang No. 41 Tahun 1999 tentang Kehutanan}

Terdapat perbedaan pengaturan dan penerapan asas ultimum remedium ataupun primum remedium dalam UU No. 5 Tahun 1967 tentang Ketentuan Pokok Kehutanan dengan UU No. 41 Tahun 1999 tentang Kehutanan. UU No. 5 Tahun 1967 tentang ketentuan Pokok kehutanan tidak mengatur sanksi pidana bilamana ada pelanggaran di bidang kehutanan. UU No. 41 Tahun 1999 tentang Kehutanan lebih menekankan penerapan asas primum remedium dalam penegakan hukum pidana di bidang kehutanan. Tindak pidana bidang kehutanan yang dapat langsung dikenakan penegakan hukum pidana adalah sebagai berikut: (pasal 78)

1. Merusak prasarana dan sarana perlindungan hutan

2. Melakukan kegiatan yang menimbulkan kerusakan hutan bagi pihak yang diberikan izin usaha pemanfaatan kawasan, izin usaha pemanfaatan izin lingkungan, izin usaha pemanfaatan hasil hutan serta pemungutan hasil hutan

3. Mengerjakan dan/atau menggunakan dan atau menduduki kawasan hutan secara tidak sah

4. Merambah kawasan hutan

Selain itu, dari segi sanksi pidana, perumusan di dalam UU No. 41 Tahun 1999 tentang Kehutanan memuat terobosan yang sebelumnya tidak pernah ada. Di dalam UU ini bahkan ganti rugi untuk pemulihan yang biasanya termasuk dalam ruang lingkup hukum perdata dimasukan kedalam ketentuan bagian hukum pidana (Pasal 80 ayat 1). Perumusan sanksi pidana di dalam UU No. 41 Tahun 1999 tentang Kehutanan ini memuat ketentuan yang memperjelas bahwa penegakan hukum administrasi, perdata dan pidana dapat dilakukan, bukan saling meniadakan.

Undang-Undang ini menyatakan bahwa sanksi administrative ataupun sanksi perdata tetap dapat diberikan. Sanksi perdata untuk membayar ganti rugi sesuai dengan tingkat kerusakan atau akibat yang ditimbulkan tidak mengurangi sanksi pidana (pasal 80 ayat $1 \mathrm{UU}$ No. 41 Tahun 1999). Sanksi administrative tetap dapat dikenakan kepada setiap pemegang izin usaha pemanfaatan kawasan, izin usaha pemanfaatan jasa lingkungan, izin usaha pemanfaatan hasil hutan walaupun sebelumnya sudah dikenakan sanksi pidana (pasal 80 ayat $2 \mathrm{UU}$ 
No. 41 Tahun 1999 tetang Kehutanan).

\section{B.2 Prinsip Ultimum Remedium dan Prinsip Primum Remedium dalam Undang-Undang No. 18 Tahun $2004 \quad$ Tentang Perkebunan}

Dalam Undang-Undang No. 18 Tahun 2004 tentang Perkebunan, perbuatan-perbuatan

dikriminalisasi adalah :

1. Sengaja atau lalai melakukan usaha budidaya tanaman perkebunan dengan luasan tanah tertentu dan/atau usaha industri pengelola hasil perkebunan dengan kapasitas tertentu tanpa memiliki Izin Usaha Perkebunan (Pasal 46)

2. Sengaja atau lalai melanggar laangan melakukan tindakan yang berakibat pada kerusakan kebun dan.atau asset lainnya (Pasal 47)

3. Sengaja ataupun lalai membuka dan/atau mengolah lahan dengan cara pembakaran yang berakibat terjadinya pencemaran dan kerusakan fungsi lingkungan hidup (Pasal 48 dan 49)

4. Dengan sengaja melanggar larangan mengiklankan hasil usaha perkebunan yang menyesatkan konsumen ( Pasal 51)

5. Dengan sengaja melanggar laragan menadah hasil usaha perkebunan yang diperoleh dari penjarahan dan/atau pencurian (Pasal 52).

Sama dengan ketentuan yang ada didalam UU No, 41 Tahun 1999 tentang Kehutanan, UU No. 18 Tahu 2004 tentang Perkebunan juga tidak memuat ketentuan yang tegas tentang penerapan asas
Ultimum Remedium. Sejalan dengan UU No. 41 Tahun 1999 tentang Kehutanan, UU No. 18 Tahun 2004 ini juga menganut perluasan kriminalisasi perbuatan di bidang usaha perkebunan. Sehingga undang-undang ini menyatakan perbuatan yang terkait dengan perizinan usaha atau kegiatan yang biasanya merupakan bagian dari Hukum Administrasi sebagai tindak pidana. Dengan demikian, penerapan Primum Remedium pada tindak pidana di bidang perkebunan tidak dilarang.

\section{B.3 Prinsip Ultimum Remedium dan Prinsip Primum Remedium dalam undang-Undang No. 4 Tahun 2009 Tentang Mineral dan Batubara}

Sama seperti UU No. 41 Tahun 1999 tentang Kehutanan dan UU No. 18 Tahun 2009 tentang Perkebunan, Ketentuan pidana di dalam Undang-Undang No. 4 Tahun 2009 tentang Mineral dan Batubara juga meluas. Perbuatanperbuatan yang dilakukan tanpa dilengkapi izin usaha atau kegiatan ditentukan sebagai tindak pidana yang diancam sanksi pidana, antara lain :

1. Melakukan usaha penambangan tanpa memiliki Izin Pertambangan (IUP, IPR atau IUPK) (Pasal 158).

2. Dengan sengaja menyampaikan laporan dengan tidak benar atau menyampaikan keterangan palsu (Pasal 159).

3. Mempunyai IUP eksplorasi tetapi melakukan kegiatan operasi produksi (Pasal 160 ayat 1). 
4. Melakukan kegiatan operasi produksi dengan IUP eksplorasi (Pasal 160 ayat 2) menampung, memanfaatkan, melakukan pengolahan dan pemurnian, pengangkutan, penjualan mineral dan batubara yang bukan dari pemegang IUP, IUPK atau izin 9Pasal 161).

5. Merintangi atau menganggu kagiatan usaha pertambangan dari pemegang IUP atau IUPK yang telah memenuhi syarat (Pasal 162)

6. Pidana tambahan bagi badan hukum dapat berupa pencabutan izin usaha dan pencabutan status badan hukum (Pasal 163).

7. Pidana tambahan bagi pelaku tindak pidana dapat berupa perampasan barang yang digunakan dalam melakukan tindak pidana, perampasan keuntungan yang diperoleh dari tindak pidana, kewajiban membayar biaya yang timbul akibat tindak pidana (Pasal 164).

Pada hakikatnya, UU No. 4 Tahun 2009 tentang Mineral dan Batubara juga tidak memuat secara tegas tentang penerapan asas Ultimum Remedium. UU No. 4 Tahun 2009 tentang Mineral dan Batubara juga menganut perluasan kriminalisasi perbuatan di bidang usaha dan kegiatan pertambangan. Sehingga undang-undang ini menyatakan perbuatan-perbuatan yang terkait dengan perizinan usaha atau kegiatan yang biasanya merupakan bagian dari Hukum Administrasi sebagai tindak pidana.

Demikian pula mengenai sanksi pidana, UU No. 4 Tahun 2009 tentang Mineral dan
Batubara mengnut perluasan sanksi pidana sehingga meliputi sanksi yang selama ini dikenal Hukum Administrasi yaitu pencabutan izin usaha dan pencabutan status badan hukum. Dengan demikian, penerapan Primum Remedium pada tindak pidana di bidang pertambangan mineral dan batubara tidak terhalang apapun.

\section{B.4 Urgensi Penerapan Prinsip Primum Remedium dalam Rangka Optimalisasi Penegakan Hukum Pidana di Bidang Lingkungan Hidup}

Berkaitan dengan sifat, fungsi dan tujuan hukum pidana, masalah pengaturan sanksi pidana, masalah pengaturan sanksi pidana dalam peraturan perundang-undangan dikenal dengan istilah Ultimum Remedium dan Primum Remedium. Makna Ultimum Remedium, bahwa sanksi pidana dipergunakan manakala sanksi yang sudah tidak berdaya. Sedangkan dalam makna Primum Remedium, sanksi pidana dipergunakan sebagai senjata utama atau yang pertama kali diancam dalam suatu ketentuan undang-undang.

Asas Ultimum Remedium dalam UU No.32 Tahun 2009 tentang Perlindungan dan Pengelolaan Lingkungan Hidup pada intinya menempatkan sarana hukum pidana sebagai obat terakhir. Artinya, bahwa pada prinsipnya, eksistensi hukum pidana dalam hukum lingkungan 
tidak lebih sebagai sarana lapis terakhir, dimana berbagai perangkat dan sarana perlindungan yang lain lebih diutamakan, sementara bila sarana tersebut dirasakan belum mencapai hasil efektif maka hukum pidana kemudian difungsikan secara efektif.

Menurut Van de Brunt, bahwa hukum pidana itu adalah Ultimum Remedium artinya ada tiga macam yaitu yang pertama ialah hukum pidana sebagai ultimum remedium karena penerapan hukum pidana itu hanya dapat dilakukan terhadap orang yang melanggar hukum secara etis sangat berat. Yang kedua ialah hukum pidana sebagai ultimum remedium karena sanksi hukum pidana lebih berat dan lebih keras daripada sanksi bidang hukum lainnya. Yang ketiga, hukum pidana adalah sebagai ultimum remedium karena pejabat administrasilah yang lebih dahulu mengetahui pelanggaran. ${ }^{3}$

M. Daud Silalahi mengungkapkan, eksistensi asas subsidaritas ini mengadopsi dari Primary Jurisdiction Doctrine yang dianut oleh negara penganut system hukum common law. Pertimbangan dimasukkanya asas ini dalam perundang-undangan di bidang lingkungan hidup adalah terkait karakteristik dasar kasuskasus lingkungan yang sangat bergantung pada penilaian keahlian. Kasus lingkungan sulit untuk dijabarkan secara hukum

\footnotetext{
${ }^{3}$ Sunarto, Hukum dan Hukum Pidana, 2007,
} Alumni, Bandung apabila tidak dilengkapi dengan pertimbangan ilmiah. ${ }^{4}$

Penerapan prinsip Primum Remedium dalam mekanisme penegakan hukum pidana lingkungan, artinya hukum pidana berada di depan dalam penegakan hukum lingkungan dan dalam hal ini penegakan hukum administrasi dan hukum perdata tetap bisa dilakukan, bahkan bersamaan. Disamping itu, dengan diterapkannya prinsip Primum Remedium dalam mekanisme penegakan hukum pidana lingkungan diharapkan $:^{5}$

1. Dapat memberikan stigma dan pencelaan kepada pelaku yang berfungsi sebagai efek pencegahan sejak dini.

2. Dengan diterapkannya prinsip Primum Remedium dalam mekanisme penegakan hukum pidana lingkungan ini kita dapat mengharapkan kepada terciptanya rexim anti pencemaran dan perusakan lingkungan hidup dimasa yang akan datang.

Jadi, ketika prinsip Premium Remedium ini diterapkan dalam mekanisme penegakan hukum lingkungan maka penyidikan dan penegakan hukum pidana melalui model scientific investigation. Artinya, penyidikan dan penegakan hukum pidana dilakukan oleh orang-orang yang memiliki keterampilan professional di bidang lingkungan.

\footnotetext{
${ }^{4}$ Lilik Mulyadi, Kompilasi Hukum Pidana Dalam Perspektif Teoritik dan Praktik Peradilan, 2007, Mandar Maju, Bandung, hlm 56

${ }^{5}$ Ibid
} 


\section{C.Kesimpulan}

Asas Ultimum Remedium dalam UU No.32 Tahun 2009 tentang Perlindungan dan Pengelolaan Lingkungan Hidup pada intinya menempatkan sarana hukum pidana sebagai obat terakhir. Artinya, bahwa pada prinsipnya, eksistensi hukum pidana dalam hukum lingkungan tidak lebih sebagai sarana lapis terakhir, dimana berbagai perangkat dan sarana perlindungan yang lain lebih diutamakan, sementara bila sarana tersebut dirasakan belum mencapai hasil efektif maka hukum pidana kemudian difungsikan secara efektif.

\section{Daftar Pustaka}

Lilik Mulyadi, Kompilasi Hukum Pidana Dalam Perspektif Teoritik dan Praktik Peradilan, 2007, Mandar Maju, Bandung

Masrudi Muchtar, Sistem Peradilan Pidana di Bidang Perlindungan dan Pengelolaan Lingkungan Hidup, 2015, Prestasi Pustaka Jakarta

Sunarto, Hukum dan Hukum Pidana, 2007, Alumni, Bandung

Undang-Undang Nomor 32 Tahun 2009 Tentang Perindungan dan Pengelolaan Lingkungan Hidup

Undang-Undang Nomor 41 Tahun 1999 Tentang Kehutanan

Undang-Undang Nomor 18 Tahun 2004 Tentang Perkebunan

Undang-Undang Nomor 4 tahun 2009 Tentang Mineral dan Batubara 